\title{
EFFICIENCY OF REDUCED VOLUME SPRAYING AIMED TO CONTROL THE Leucoptera coffeella (LEPIDOPTERA: LYONETIIDAE)
}

\author{
EFICIÊNCIA DA PULVERIZAÇÃO EM VOLUME REDUZIDO VOLTADA AO \\ CONTROLE DE Leucoptera coffeella (LEPIDOPTERA: LYONETIIDAE)
}

\section{Olinto LASMAR'; ; Marcelo da Costa FERREIRA²; Sergio Tadeu DECARO JUNIOR; Gunther FOUQUET ${ }^{4}$}

1. Engenheiro Agrônomo, Doutor em Entomologia Agrícola, Faculdade de Ciências Agrarias e Veterinária - FCAV, Universidade Estadual Paulista - UNESP, Jaboticabal, SP, Brasil; 2. Professor, Doutor, Depto. de Fitossanidade, FCAV/UNESP, Jaboticabal, SP Brasil; 3. Engenheiro Agrônomo, Doutor em Produção Vegetal, FCAV/UNESP, Jaboticabal, SP, Brasil; 4. Engenheiro Mecânico, Pulsfog Pulverizadores, Diadema, SP, Brasil

\begin{abstract}
The objective of the study was to evaluate the application efficiency with reduced volume from the prototype of a pneumatic spray nozzles aimed to control the coffee leaf miner (Leucoptera coffeella). We evaluated different types of pneumatic nozzles (flat fan, cone jet, AT-1000 model and effervescent), on application of insecticide spray liquids with concentrations of 5,10,15 and 20\% (v/v) of mineral oil applied in reduced volume and $0.5 \%$ applied by conventional airblast sprayer. The application technology parameters studied in laboratory and field conditions were as follows: droplet size $(\mu \mathrm{m})$, tracer deposit $\left(\mu \mathrm{g} / \mathrm{cm}^{2}\right)$ and leaf spray coverage $(\%)$. The reduced volume application, provided by the prototype of a pneumatic spray nozzles with the effervescent type compared to traditional airblast sprayer, presents proper conditions of use, especially in relation to deposit and coverage of spraying liquid over coffee leaves.
\end{abstract}

KEYWORDS: Coffea Arabica. Application technology. Volume reduction. Droplets.

\section{INTRODUCTION}

The leaf miner is a good example to demonstrate the economically importance of the target insects for coffee crop. Its control is performed mainly through the application of synthetic insecticides, which if used without the necessary technological knowledge, can contaminate humans and the environment and cause biological imbalances that result in an increase in secondary pests and in the selection of insecticideresistant populations (SHARMA, 2008).

Turbo atomizers are currently used, and they were developed to reduce labor costs, decreasing the necessary operators from two to one, and, furthermore, the air flow of this equipment directs the sprayed droplets in the direction of the target, improving their penetration and consequent deposition (BALAN, ABI SAAB; SASAKI, 2006).

Another important mode of application is spraying reduced volume, typically used in pneumatic sprayers. These devices are based on the pneumatic spraying process, which is the shock of an air flow at high speed and moderate pressure with a liquid conveyed by gravity or low pressure (MATTHEWS, 2000).

According Minguela and Cunha (2010), the pneumatic circuit consists of a radial fan driven by the power take-off with an intermediate transmission multiplier. To allow different flows and air speeds, should the mechanical transmission has different speeds. The rotating speed allows to obtain a population of fine droplets, from 100 to 250 $\mu \mathrm{m}$ and generally very uniform, which allows applications to perform low volume (50-100 1/ha), including ultra low volume.

There are reduced volume sprayers using pneumatic nozzles (gaseous energy) for the production of uniform droplets of adequate size (MEWES et al., 2015). These nozzles are increasingly used for sprayings in urban areas for the control of disease-transmitting insects, although they also have long been used in agriculture (WOLRD HEALTH ORGANIZATION, 1990).

Effervescent nozzles are a type of pneumatic nozzle developed by Lefebvre and collaborators in the 1980s (LEFEBVRE; WANG; MARTYN, 1988). Effervescent atomization is a method of twin-fluid atomization that involves bubbling a small amount of gas into the liquid before it is ejected from the atomizer. The technique of bubbling gas directly into the liquid stream inside the atomizer body is essentially different from other methods of twin-fluid atomization (either internal or external mixing) and leads to significant improvements in performance in terms of smaller drop sizes and lower injection pressures (OCHOWIAK; BRONIARZS-PRESS, 2008).

The objective of the study was to evaluate the application efficiency with reduced volume from the prototype of a pneumatic spray nozzles on control the coffee leaf miner L. coffeella. 


\section{MATERIAL AND METHODS}

Laboratory analyses of droplet sizes, coverage and deposition of a tracer on coffee leaves were performed at the Center for Applied Technology Studies and Development (NEDTA) of the Crop Protection Department, Jaboticabal campus, São Paulo State University (UNESP) during 2012 and 2013. Field experiments were performed in coffee plants Coffea arabica plots located in coffee-producing regions of the Altinópolis and Ribeirão Corrente municipalities, SP.

\section{Assessment of droplet size}

A laser particle analyzer was used for the measurement of volume median diameter (VMD) and the uniformity coefficient (COEF) of the droplets formed by the different types of pneumatic nozzles: flat fan, cone jet, AT-1000 model, and effervescent.

Two air pressures were adopted for the sprayer compressor (30 and $40 \mathrm{kPa}$ ), which was adjusted to two working speeds $(5.3$ and $7.5 \mathrm{~km} / \mathrm{h}$, respectively), and four concentrations of oil-based (Argenfrut $^{\circledR}$ ) spray liquid $(5,10,15$, and $20 \% \mathrm{v} / \mathrm{v}$ ) were used. The experimental design was completely randomized, with a factorial scheme of $4 \times 5$ (nozzles x spray liquids) and six replicates. Water was used as a control.

The analysis of the droplet spectrum was performed directly, through the laser diffraction method, using a particle analyzer (Mastersizer $S^{\circledR}$, Malvern Instruments Co.). This method is based on light deflection following its collision with the droplets, as the droplet diameter is inversely proportional to the light deflection angle (FERNANDES et al., 2007).

The spraying nozzles were set up statically $40 \mathrm{~cm}$ from the laser beam and positioned so that the entire spray crossed the light beam. To maintain a constant spray pressure, compressed air, which was controlled by a pressure regulator that was manually operated and equipped with an analog manometer calibrated for this purpose, was used. The data were treated using an algorithm created for the characterization of particle diameter by laser diffraction using the Mastersizer S V.2.19 software (Malvern Instruments Co).

The data were subjected to an analysis of variance using an $\mathrm{F}$ test and the means were compared using Tukey's test $(\mathrm{p} \leq 0.05)$.

\section{Assessment of spray deposition and coverage - Experiment 1}

The first field experiment was performed between April and May 2012 at the Altinópolis municipality, SP, at an altitude of approximately 987 meters. The experimental plots consisted of 20 plants of the cultivar Catuaí IAC-99, which were approximately 12 years old and had a mean height of $2.50 \mathrm{~m}$. According to the scale proposed by Camargo et al. (2001), the crop was in the vegetative phase, with a good level of leaf production.

The reduced volume treatments were applied in a volume of approximately 70 1/ha by means of a prototype sprayer version 2012 (PRV 12). This sprayer is based on the Smart $400 \mathrm{ULV}$ model (Sprayers Inc. Pulsfog ${ }^{\circledR}$ ).

For the applications we used an insecticide (treatment of farm) registered for coffee crop, an insecticide (profenofos + lufenuron) at a dosage of $800 \mathrm{~mL}$ commercial product (c.p.)/ha and with different concentrations of the mineral oil Argenfrut $^{\circledR}(5,10,15$, and 20\%) was used as the spray liquid. The sprayer was equipped with a flat spray pneumatic nozzle with disc 06 and $310 \mathrm{kPa}$ pressure at the spray tank pressurized with $\mathrm{CO}_{2}$.

A randomized block experimental design was used, with six treatments and four replicates. Two controls were prepared, one negative (no application) and one positive (application using a tractor-mounted airblast Arbus 400 Jacto $^{\circledR}$ ). The application volume was approximately $400 \mathrm{l} / \mathrm{ha}$, with 16 hydraulic spraying nozzles JA-2 model, with a working pressure of $1000 \mathrm{kPa}$.

A compact Massey Ferguson 275 tractor with a 1900 RPM engine and 540 RPM power takeoff was used with the two tested sprayers.

The tracer manganese sulfate $(20 \mathrm{~g} / \mathrm{l})$ was added to the spray liquids for the quantification of the spray deposition on coffee leaves. Because the same tracer concentration was used for all treatments, a mathematical correction was performed according to the spray volumes for statistical comparison of the mean deposit values. The deposit data obtained for the smaller volume (1/ha) were multiplied by a correction factor $(C F)$ obtained using the following equation: $C F=l a v /$ $s m v$, where $C F$ is the correction factor, lav is the value for the largest volume, and $s m v$ is the value for the smallest volume (FERREIRA; LEITE; LASMAR, 2013).

The data for the climate conditions during each treatment are shown in Table 1. 
Table 1. Climate conditions during the applications to coffee crop of experiment 1.

\begin{tabular}{lccccc}
\hline \multirow{2}{*}{ Treatments* } & \multicolumn{5}{c}{ Applications } \\
\cline { 2 - 6 } & Date & Hour & Air Temp. $\left({ }^{\circ} \mathrm{C}\right)$ & RH $(\%)$ & Wind $(\mathrm{km} / \mathrm{h})$ \\
\hline 1. PRV-12 (5\% MO) & $04 / 26 / 2012$ & $12: 40$ & 20.6 & 89 & 2.3 \\
2. PRV-12 (10\% MO) & $04 / 26 / 2012$ & $13: 12$ & 20.9 & 88 & 5.5 \\
3. PRV-12 (15\% MO) & $04 / 26 / 2012$ & $13: 45$ & 22.5 & 80 & 6.2 \\
4. PRV-12 (20\% MO) & $04 / 26 / 2012$ & $14: 15$ & 23.8 & 73 & 5.0 \\
5. Arbus 400 (0,5\% MO) & $04 / 27 / 2012$ & $10: 30$ & 23.4 & 57 & 5.4
\end{tabular}

*Wind speed was measured in the interior of the crop. The application volume was 70 1/ha for treatments $1,2,3$, and 4 and $4001 /$ ha for treatment 5. MO: mineral oil.

The plots consisted of five rows of 30 plants, with two rows on each side used as windbreakers and borders and the central row designated as the useful area. In the central row, two central plants were used for the collection of leaf samples for the quantification of spray deposition. The remaining plants in the useful area were used as the border.

Leaves for the assessment of droplet deposition were collected approximately 30 minutes following treatment from four positions (two leaves per position), each located at a different plant quadrant: the highest part of the plant and four from the lower part of the plant crown, at a height of approximately $0.5 \mathrm{~m}$ from the soil. A total of 128 leaves per treatment were analyzed, two for each of the eight positions, from two plants per plot, with four replicates.

The collected leaves were placed in plastic bags, labeled, and taken to the NEDTA laboratory. The samples received $100 \mathrm{ml} 0.2 \mathrm{~N} \mathrm{HCl}$ and were left to stand for 60 minutes for the dissolution of the applied salts according to Oliveira and MachadoNeto (2003). The resulting extract was filtered, and the recovered $\mathrm{Mn}^{2+}$ was quantified using an atomic absorption spectrophotometer. The leaves were washed, and the leaf areas (true leaf area indexTLAI) were measured using a LI-Cor portable leaf area meter (LI-3000 A) for the calculation of the tracer amount recovered per leaf area $(\mu \mathrm{g}$ tracer $/ \mathrm{cm}^{2}$ ).

The spray coverage of the leaf surface was evaluated using water-sensitive paper directly stapled to the leaves. The papers were placed at eight different points on the crown of each plant, from four quadrants and at two heights (approximately $0.5 \mathrm{~m}$ and $2.5 \mathrm{~m}$ from the ground). The same criteria adopted for the evaluation of spray deposition were followed, i.e., the collection was performed following the drying of the leaves. The papers were then removed, placed in Petri dishes to protect them from exposure to moisture, and taken to the laboratory mentioned above. The Quant $2002^{\circledR}$ software was used for the image analysis, which quantifies the percentage area covered by the spots produced by the droplets by calculating the difference between the total area and the covered area (FERNANDES FILHO et al., 2002).

The data were subjected to an analysis of variance using the $\mathrm{F}$ test, followed by Tukey's test at $\mathrm{p} \leq 0.05$. The coverage data were arc.sen $(\mathrm{x} / 100)^{1 / 2}$ transformed, and the deposit data were ( $\mathrm{x}$ $+0.5)^{1 / 2}$ transformed to meet the assumption of homogeneity of variance.

\section{Assessment of spray deposition and coverage - Experiment 2}

A second field experiment was conducted in the period August-September 2013 in Ribeirão Corrente municipality, SP. The coffee plantation used belongs to the farm located in Bela Época Coffees at altitude of approximately 900 meters. The experimental plots consisted of 20 plants of the cultivar Mundo Novo IAC 379/19, approximately 5 years old and with a mean height of $3.0 \mathrm{~m}$. According to the scale proposed by Camargo et al. (2001), this crop was also in the vegetative phase with a good level of leaf production.

The methodology used in this second experiment was similar to the first, except that some modifications were made in the prototype sprayer for reduced volume.

Reduced volume treatments were applied in a volume of approximately $100 \mathrm{l} / \mathrm{ha}$ using a prototype sprayer version 2013 (PRV-13). For the applications we used an insecticide (treatment of farm) registered for coffee crop, (lambdacyhalothrin + chlorantraniliprole) at a dosage of 315 $\mathrm{ml}$ c.p./ha and with different concentrations of the mineral oil Argenfrut ${ }^{\circledR}(5,10,15$, and 20\%) was used as the spray liquid. The sprayer was equipped with an effervescent pneumatic nozzle, and the 
compressor air pressure was adjusted to $60 \mathrm{kPa}$ air flow.

The experimental design was the same as described for experiment 1. However, the conventional sprayer used was an Arbus 2000 Jacto $^{\circledR}$, with an application volume of approximately 400 1/ha, with 22 hydraulic spraying nozzles JA-2 model and working pressure of $415 \mathrm{kPa}$ and without a "T" auxiliary extension.

A compact Yanmar 1155 tractor with a 2000 RPM engine and 540 RPM power take-off was used for the two sprayers tested. The data for the climate conditions during the treatments are shown in Table 2.

Table 2. Climate conditions during the applications to coffee crop of experiment 2.

\begin{tabular}{lccccc}
\hline \multirow{2}{*}{ Treatments* } & \multicolumn{5}{c}{ Applications } \\
\cline { 2 - 5 } & Date & Hour & Air Temp. $\left({ }^{\circ} \mathrm{C}\right)$ & $\mathrm{RH}(\%)$ & Wind $(\mathrm{km} / \mathrm{h})$ \\
\hline 1. PRV-13 (5\% MO) & $08 / 15 / 2013$ & $13: 45$ & 21.9 & 37 & 1.5 \\
2. PRV-13 (10\% MO) & $08 / 15 / 2013$ & $14: 35$ & 22.0 & 37 & 1.5 \\
3. PRV-13 (15\% MO) & $08 / 14 / 2013$ & $17: 00$ & 21.1 & 68 & 1.5 \\
4. PRV-13 (20\% MO) & $08 / 14 / 2013$ & $17: 40$ & 18.1 & 75 & 1.5 \\
5. Arbus 2000 (0,5\% MO) & $08 / 14 / 2013$ & $11: 00$ & 23.3 & 55 & 1.5 \\
\hline
\end{tabular}

*Wind speed was measured in the interior of the crop. The application volume was 70 1/ha for treatments $1,2,3$, and 4 and 400 1/ha for treatment 5. MO: mineral oil.

All methods used for the quantification of spray deposition and coverage and the statistical analyses were as previously described.

\section{RESULTS AND DISCUSSION}

\section{Assessment of droplet size}

The highest VMD values were obtained using the effervescent nozzle at the two air pressures
(30 and $40 \mathrm{kPa}$ ) and for all spray liquids tested, with means of 110.80 and $74.69 \mu \mathrm{m}$, respectively. Furthermore, the droplet spectrum was uniform (COEF), which is also interesting for application quality. The other evaluated nozzles (flat fan, cone jet, and AT-1000 model) yielded significantly lower values for these DMV work pressures.

Table 3. Volume median diameter (VMD $\mu \mathrm{m}$ ) and uniformity coefficient (COEF) of droplets obtained using different pneumatic nozzles, air pressures and mineral oil concentrations in spray liquids.

\begin{tabular}{|c|c|c|c|c|c|c|c|c|}
\hline \multirow{3}{*}{ Treatments } & \multicolumn{4}{|c|}{$\mathrm{VMD}(\mu \mathrm{m})$} & \multicolumn{4}{|c|}{$\mathrm{COEF}$} \\
\hline & \multicolumn{4}{|c|}{$30^{\dagger}$} & \multicolumn{4}{|c|}{30} \\
\hline & flat fan & cone jet & AT-1000 & effervescent & flat fan & cone jet & AT-1000 & effervescent \\
\hline 1. Water & $35.41 \mathrm{Ba}$ & $23.85 \mathrm{Ca}$ & $22.52 \mathrm{Ca}$ & $103.64 \mathrm{Ad}$ & $3.94 \mathrm{Ac}$ & $1.31 \mathrm{Ca}$ & $1.24 \mathrm{Ca}$ & $2.07 \mathrm{Ba}$ \\
\hline 2. MO 5\% & $27.85 \mathrm{Bbc}$ & $23.77 \mathrm{Ca}$ & $22.74 \mathrm{Ca}$ & $108.14 \mathrm{Ac}$ & $4.54 \mathrm{Ab}$ & $1.31 \mathrm{Ca}$ & $1.23 \mathrm{Ca}$ & $2.00 \mathrm{Ba}$ \\
\hline 3. MO $10 \%$ & $28.75 \mathrm{Bb}$ & $23.66 \mathrm{Ca}$ & $22.62 \mathrm{Ca}$ & 109.63 Ac & $5.38 \mathrm{Aa}$ & $1.32 \mathrm{Ca}$ & $1.22 \mathrm{Ca}$ & $2.08 \mathrm{Ba}$ \\
\hline 4. MO $15 \%$ & $28.55 \mathrm{Bbc}$ & $24.28 \mathrm{Ca}$ & $22.87 \mathrm{Ca}$ & $118.33 \mathrm{Aa}$ & $5.39 \mathrm{Aa}$ & $1.32 \mathrm{Ca}$ & $1.23 \mathrm{Ca}$ & $2.20 \mathrm{Ba}$ \\
\hline 5. MO $20 \%$ & $25.96 \mathrm{Bc}$ & $23.28 \mathrm{Ca}$ & $22.58 \mathrm{Ca}$ & $114.24 \mathrm{Ab}$ & $3.66 \mathrm{Ad}$ & $1.33 \mathrm{Ca}$ & $1.23 \mathrm{Ca}$ & $2.26 \mathrm{Ba}$ \\
\hline Mean & 29.30 & 23.77 & 22.67 & 110.80 & 4.58 & 1.32 & 1.23 & 2.12 \\
\hline $\mathrm{VC}(\%)$ & & & 55 & & & & .56 & \\
\hline \multirow{3}{*}{ Treatments } & \multicolumn{4}{|c|}{ VMD $(\mu \mathrm{m})$} & \multicolumn{4}{|c|}{ COEF } \\
\hline & \multicolumn{4}{|c|}{$40^{\dagger}$} & \multicolumn{4}{|c|}{40} \\
\hline & flat fan & cone jet & AT-1000 & effervescent & flat fan & cone jet & AT-1000 & effervescent \\
\hline 1. Water & $23.81 \mathrm{Ba}$ & $18.03 \mathrm{Ca}$ & $18.48 \mathrm{Cb}$ & $75.46 \mathrm{Aab}$ & $3.94 \mathrm{Ab}$ & $1.16 \mathrm{Ca}$ & $1.12 \mathrm{Ca}$ & $2.07 \mathrm{Ba}$ \\
\hline 2. MO 5\% & $20.29 \mathrm{Bb}$ & $18.04 \mathrm{Ca}$ & $18.74 \mathrm{BCb}$ & $76.57 \mathrm{Aa}$ & $4.03 \mathrm{Ab}$ & $1.16 \mathrm{Ca}$ & $1.12 \mathrm{Ca}$ & $1.94 \mathrm{Ba}$ \\
\hline 3. MO $10 \%$ & $21.63 \mathrm{Bb}$ & $18.04 \mathrm{Ca}$ & $21.25 \mathrm{Ba}$ & $70.29 \mathrm{Ac}$ & $5.28 \mathrm{Aa}$ & $1.15 \mathrm{Ca}$ & $1.10 \mathrm{Ca}$ & $1.97 \mathrm{Ba}$ \\
\hline 4. MO $15 \%$ & $21.25 \mathrm{Bb}$ & $18.50 \mathrm{Ca}$ & $18.60 \mathrm{Cb}$ & $74.62 \mathrm{Ab}$ & $5.40 \mathrm{Aa}$ & $1.20 \mathrm{Ca}$ & $1.12 \mathrm{Ca}$ & $1.91 \mathrm{Ba}$ \\
\hline 5. MO $20 \%$ & $19.92 \mathrm{Bb}$ & $18.06 \mathrm{Ca}$ & $18.54 \mathrm{BCb}$ & $76.51 \mathrm{Aa}$ & $3.49 \mathrm{Ac}$ & $1.17 \mathrm{Ca}$ & $1.12 \mathrm{Ca}$ & $1.94 \mathrm{Ba}$ \\
\hline Mean & 21.38 & 18.13 & 19.12 & 74.69 & 4.43 & 1.17 & 1.12 & 1.97 \\
\hline $\mathrm{VC}(\%)$ & \multicolumn{4}{|c|}{3.50} & \multicolumn{4}{|c|}{4.65} \\
\hline
\end{tabular}

Means followed by the same upper case letters within the same row, and lower case letters within the same column, are not significantly different according to Tukey’s test $(\mathrm{p} \leq 0.05)$. ${ }^{\dagger}$ Air pressure values $(\mathrm{kPa})$ generated by the sprayer compressor. MO: mineral oil Argenfrut $^{\circledR}$. 
As expected, the higher air pressure (40 $\mathrm{kPa}$ ) gave lower VMD droplets in all the nozzles, however, continued to discriminate between types of nozzles. In Figure 1 we present the averages of
DMV and COEF only to the pressure of $40 \mathrm{kPa}$, indicating a significant difference between the types evaluated pneumatic nozzles.

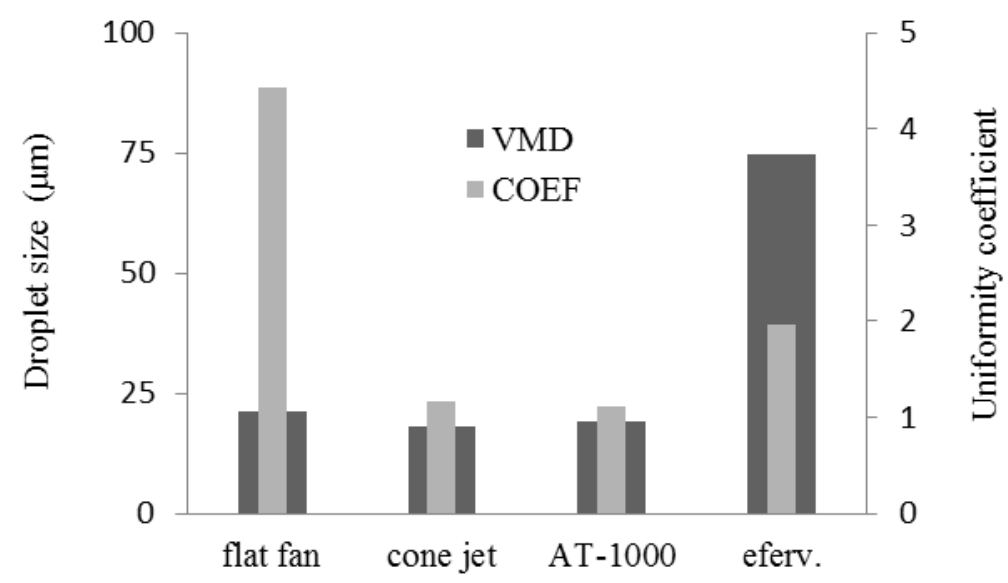

Figure 1. Volume median diameter $(\mathrm{VMD} \mu \mathrm{m})$ and uniformity $(\mathrm{COEF})$ for the tested models of pneumatic nozzles with $40 \mathrm{kPa}$ air pressure.

VMD and COEF should be analyzed together for a better characterization of the spraying. VMD gives a reference value without indicating the data dispersion around that value, whereas COEF indicates the homogeneity of the droplet spectrum (CUNHA; BUENO; FERREIRA, 2010). Therefore, in addition to evaluating the effects of adjuvants and other factors that affect droplet size, it is also important to evaluate the effect on droplet uniformity.

Therefore, the effervescent pneumatic nozzle, with an air pressure of $40 \mathrm{kPa}$ exhibited the best results for use with the prototype sprayer for reduced volume in coffee crop, according to the droplet size and uniformity because a VMD closer to $100 \mu \mathrm{m}$ was the goal.

\section{Assessment of spray deposition and coverage - Experiment 1}

The tracer deposition on coffee leaves in different locations of the plant crown (four upper quadrants and four lower quadrants) indicated that the PRV-12 pneumatic sprayer resulted in lower deposition than the conventional airblast Arbus 400 sprayer, on average (Table 4).

Mean deposition values for all treatments were lower in quadrants II and IV (internal plant crown locations) than in quadrants I and III (external plant crown locations), which was expected considering the volume of the spray applied (70 1/ha) and the low kinetic energy of the droplets produced by this version of the prototype sprayer for reduced volume.

Another factor that may have had a negative effect on the quality of applications was droplet evaporation, especially for the lower mineral oil concentrations. This factor was reported by Matthews (2000), who observed that at optimal temperature and relative air humidity $\left(20^{\circ} \mathrm{C}\right.$ and $80 \%$ humidity), a $50 \mu \mathrm{m}$ diameter droplet lasts approximately 14 seconds and can travel $0.5 \mathrm{~m}$, whereas in the worst conditions $\left(30^{\circ} \mathrm{C}\right.$ and $50 \%$ humidity), the duration of the same droplet size would be 4 seconds, and it would only travel 0.15 m.

It should be noted that flat spray nozzles were used in this version of the pneumatic sprayer (PRV-12), which resulted in very narrow droplets, with VMD lower than $25 \mu \mathrm{m}$ and low uniformity of the droplet spectrum (Table 3 and Figure 1).

Significant differences in the percentage spray coverage of the coffee plants' upper third sections were observed between treatments, especially in quadrants I and III. The treatment with the Arbus 400 sprayer and $0.5 \%$ mineral oil exhibited the highest values, followed by PRV-12 with $20 \%$ mineral oil (Figure 2). It should be noted that both sprayers exhibited difficulties in reaching the upper thirds of the coffee plants because the coverage percentages were lower than $40 \%$ in that area (Figure 2). 
Table 4. Means of depositions $\left(\mu \mathrm{g} / \mathrm{cm}^{2}\right)$ in leaves of each quadrant of the upper and lower parts of coffee plants following the applications using two sprayers, prototype for reduced volume version 2012 and conventional.

\begin{tabular}{|c|c|c|c|c|c|c|c|c|}
\hline \multirow{3}{*}{$\begin{array}{l}\text { Treatments } \\
1 . \text { PRV-12 (5\% MO*) }\end{array}$} & \multicolumn{7}{|c|}{ Deposit in coffee leaves $\left(\mu \mathrm{g} / \mathrm{cm}^{2}\right)$} & \multirow{3}{*}{$\frac{\text { Average quadrants }}{0.97 \mathrm{~b}}$} \\
\hline & \multicolumn{2}{|c|}{ Upper I } & \multicolumn{2}{|c|}{ Upper II } & \multicolumn{2}{|c|}{ Upper III } & Upper IV & \\
\hline & 2.00 & $\mathrm{Ab}$ & 0.34 & $\mathrm{Ba}$ & 0.91 & $\mathrm{ABb}$ & $0.63 \mathrm{ABa}$ & \\
\hline 2. PRV-12 (10\% MO) & 2.74 & $\mathrm{ABab}$ & 1.37 & $\mathrm{BCa}$ & 3.71 & $\mathrm{Aa}$ & 0.80 & $2.16 \mathrm{ab}$ \\
\hline 3. PRV-12 (15\% MO) & 4.06 & $\mathrm{Aab}$ & 0.80 & $\mathrm{Ba}$ & 1.14 & $\mathrm{Bab}$ & 0.69 & $1.67 \mathrm{ab}$ \\
\hline 4. PRV-12 (20\% MO) & 4.46 & $\mathrm{Aa}$ & 1.09 & $\mathrm{Ba}$ & 2.17 & $\mathrm{ABab}$ & 0.57 & $2.07 \mathrm{ab}$ \\
\hline 5. Arbus $400(0,5 \% \mathrm{MO})$ & 4.86 & $\mathrm{Aa}$ & 1.42 & $\mathrm{Ba}$ & 3.44 & $\mathrm{Aa}$ & 0.70 & $2.61 \mathrm{a}$ \\
\hline $\mathrm{VC}(\%)^{\dagger}$ & & & & & 94 & & & 14,45 \\
\hline \multirow{2}{*}{ Treatments } & \multicolumn{7}{|c|}{ Deposit in coffee leaves $\left(\mu \mathrm{g} / \mathrm{cm}^{2}\right)$} & \\
\hline & \multicolumn{2}{|c|}{ Lower I } & \multicolumn{2}{|c|}{ Lower II } & \multicolumn{2}{|c|}{ Lower III } & Lower IV & Average quadrants \\
\hline 1. PRV-12 (5\% MO*) & 2.06 & $\mathrm{Ab}$ & 0.23 & $\mathrm{Ba}$ & 2.23 & $\mathrm{Ab}$ & 0.29 & $1.20 \mathrm{c}$ \\
\hline 2. PRV-12 (10\% MO) & 3.09 & $\mathrm{Ab}$ & 0.80 & $\mathrm{Ba}$ & 3.71 & Aab & 0.74 & $2.09 \mathrm{~b}$ \\
\hline 3. PRV-12 (15\% MO) & 3.14 & $\mathrm{Ab}$ & 0.69 & $\mathrm{Ba}$ & 3.14 & $\mathrm{Aab}$ & 0.74 & $1.93 \mathrm{bc}$ \\
\hline 4. PRV-12 (20\% MO) & 3.26 & $\mathrm{Aab}$ & 0.74 & $\mathrm{Ba}$ & 4.80 & $\mathrm{Aab}$ & 0.74 & $2.39 \mathrm{~b}$ \\
\hline 5. Arbus $400(0,5 \% \mathrm{MO})$ & 6.24 & $\mathrm{Aa}$ & 1.40 & $\mathrm{Ba}$ & 5.42 & $\mathrm{Aa}$ & 1.38 & $3.61 \mathrm{a}$ \\
\hline $\mathrm{VC}(\%)^{\dagger}$ & \multicolumn{7}{|c|}{22.72} & 7.76 \\
\hline
\end{tabular}

Means followed by the same upper case letters within the same row, and lower case letters within the same column, are not significantly different according to Tukey's test $(\mathrm{p} \leq 0.05)$. ${ }^{*} \mathrm{MO}$ : mineral oil Argenfrut ${ }^{\circledR}$. ${ }^{\dagger}$ Data $(\mathrm{x}+0.5)^{1 / 2}$ transformed.

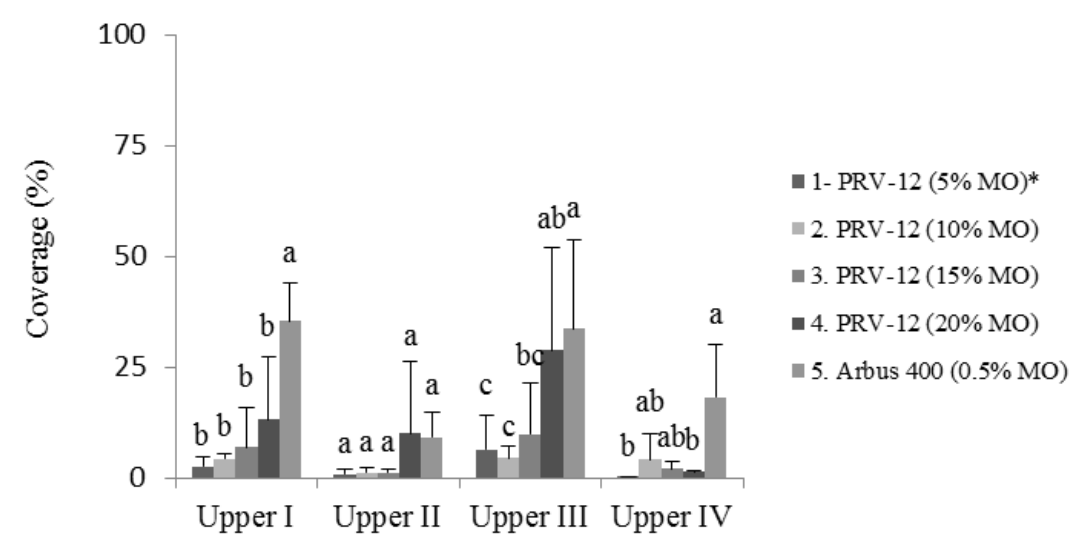

Figure 2. Mean coverage (\%) of water-sensitive paper for each quadrant of the upper parts of coffee plants. VC $=5.60 \%$. Means followed by the same letter for each quadrant were not significantly different according to Tukey's test $(\mathrm{p} \leq 0.05)$. *MO: mineral oil Argenfrut ${ }^{\circledR}$. ${ }^{\dagger}$ Data $\operatorname{arc} . \operatorname{sen}(x / 100)^{1 / 2}$ transformed.

Ferreira, Leite and Lasmar (2013) evaluated spray droplet coverage and deposition on coffee plants using sprayers with and without an auxiliary extension for high plants and reported difficulty in reaching the upper thirds of the plants, which is in agreement with the present study.
Significant differences were observed for the lower thirds of the coffee plants in all quadrants. However, these differences were only substantial for the treatment with Arbus 400 with $0.5 \%$ mineral oil, which corresponded to values of $80 \%$ in quadrants I and III and 50\% in quadrants II and IV (Figure 3). 


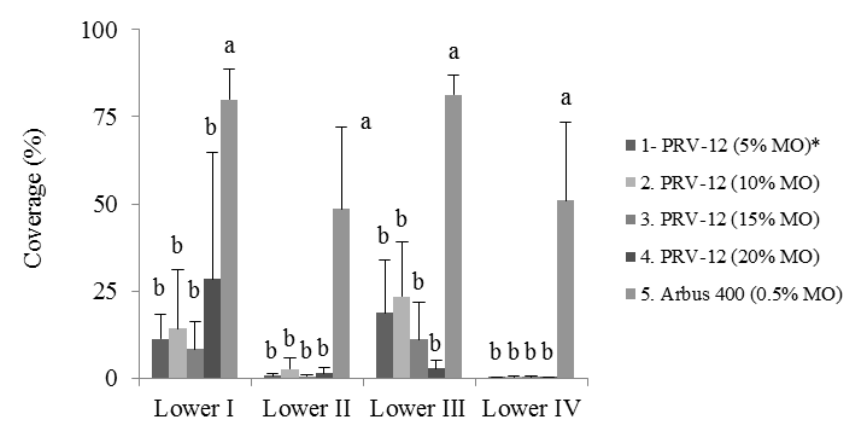

Figure 3. Mean coverage (\%) of water sensitive paper for each quadrant of the lower parts of coffee plants. VC $=6.01 \%$. Means followed by the same letter for each quadrant were not significantly different according to Tukey's test $(\mathrm{p} \leq 0.05)$. *MO: mineral oil Argenfrut ${ }^{\circledR}$. ${ }^{\dagger}$ Data $\operatorname{arc} . \operatorname{sen}(\mathrm{x} / 100)^{1 / 2}$ transformed.

\section{Assessment of spray deposition and coverage - Experiment 2}

Despite the weather conditions recorded in this experiment were not ideal, especially in relation to the use of fine droplets (Table 2), it is noteworthy that the observed deposit and coverage amounts provided significant differences in adverse conditions relative humidity.

A significant difference in spray deposition was observed on the upper parts of the coffee plants crowns in the first and second quadrants and in the overall mean deposition of the quadrants (Table 6). Use of the PRV-13 sprayer with 100 1/ha resulted in larger deposits in the first quadrant, with no differences between different mineral oil concentrations $(5,10,15$, and $20 \%)$. However, the values were higher than those for the Arbus 2000 sprayer, which was calibrated to $400 \mathrm{l} / \mathrm{ha}$ and used $0.5 \%$ mineral oil in the spray liquid. The latter sprayer is commonly used at the farm where the experiment was performed.

The deposition results were better in the lower thirds of the plants, especially for quadrants I and III (crown external positions), and for the overall mean deposition for all quadrants, especially for PRV-13 sprayer. No significant differences were observed with different concentrations of mineral oil in the spray liquid but deposition was significantly higher for the PRV-13 sprayer than for the conventional sprayer Arbus 2000 (Table 6).

Table 6. Means of depositions $\left(\mu \mathrm{g} / \mathrm{cm}^{2}\right)$ in leaves of each quadrant of the upper and lower parts of coffee plants following the applications using two sprayers, prototype for reduced volume version 2013 and conventional.

\begin{tabular}{|c|c|c|c|c|c|c|c|}
\hline \multirow{3}{*}{$\begin{array}{l}\text { Treatments } \\
\text { 1. PRV-13 (5\% MO*) }\end{array}$} & \multicolumn{6}{|c|}{ Deposit in coffee leaves $\left(\mu \mathrm{g} / \mathrm{cm}^{2}\right)$} & \multirow{3}{*}{$\frac{\text { Average quadrants }}{15.70 \mathrm{a}}$} \\
\hline & \multicolumn{2}{|c|}{ Upper I } & \multicolumn{2}{|c|}{ Upper II } & Upper III & Upper IV & \\
\hline & 24.49 & $\mathrm{Aa}$ & 9.97 & $\mathrm{ABab}$ & $19.12 \mathrm{ABa}$ & $9.22 \mathrm{Ba}$ & \\
\hline 2. PRV-13 (10\% MO) & 30.02 & $\mathrm{Aa}$ & 12.27 & Aab & 17.30 & $13.08 \mathrm{Aa}$ & $18.17 \mathrm{a}$ \\
\hline 3. PRV-13 (15\% MO) & 20.39 & $\mathrm{Aa}$ & 19.34 & $\mathrm{Aa}$ & 8.49 & 16.18 Aa & $16.10 \mathrm{a}$ \\
\hline 4. PRV-13 (20\% MO) & 20.86 & $\mathrm{Aa}$ & 14.83 & Aab & 6.82 & 12.29 Аа & $13.70 \mathrm{a}$ \\
\hline 5. Arbus $400(0,5 \% \mathrm{MO})$ & 2.14 & $\mathrm{Ab}$ & 3.37 & $\mathrm{Ab}$ & 3.62 & $3.52 \mathrm{Aa}$ & $3.16 \mathrm{~b}$ \\
\hline $\mathrm{VC}(\%)^{\dagger}$ & & & & 32.1 & & & 18.34 \\
\hline \multirow{2}{*}{ Treatments } & \multicolumn{6}{|c|}{ Deposit in coffee leaves $\left(\mu \mathrm{g} / \mathrm{cm}^{2}\right)$} & \\
\hline & \multicolumn{2}{|c|}{ Lower I } & \multicolumn{2}{|c|}{ Lower II } & Lower III & Lower IV & Average quadrants \\
\hline 1. PRV-13 (5\% MO*) & 44.66 & $\mathrm{Aa}$ & 7.08 & $\mathrm{Ba}$ & $32.45 \mathrm{Aa}$ & $10.57 \mathrm{Ba}$ & $23.69 \mathrm{a}$ \\
\hline 2. PRV-13 (10\% MO) & 38.17 & $\mathrm{Aa}$ & 11.52 & $\mathrm{Ba}$ & 39.07 & $10.70 \mathrm{Ba}$ & $24.87 \mathrm{a}$ \\
\hline 3. PRV-13 (15\% MO) & 38.24 & $\mathrm{Aa}$ & 17.63 & $\mathrm{Ba}$ & $31.72 \mathrm{ABa}$ & $14.91 \mathrm{Ba}$ & $25.62 \mathrm{a}$ \\
\hline 4. PRV-13 (20\% MO) & 36.94 & $\mathrm{Aa}$ & 11.11 & $\mathrm{Ba}$ & $25.79 \mathrm{ABa}$ & 10.09 & $20.98 \mathrm{a}$ \\
\hline 5. Arbus $400(0,5 \% \mathrm{MO})$ & 5.14 & $\mathrm{Ab}$ & 4.62 & Aa & $5.86 \mathrm{Ab}$ & 4.20 & $4.95 \mathrm{~b}$ \\
\hline $\mathrm{VC}(\%)^{\dagger}$ & \multicolumn{6}{|c|}{24.67} & 16.84 \\
\hline
\end{tabular}

Means followed by the same upper case letters within the same row, and lower case letters within the same column, are not significantly different according to Tukey's test $(\mathrm{p} \leq 0.05)$. *MO: mineral oil Argenfrut ${ }^{\circledR}$. ${ }^{\dagger}$ Data $(x+0.5)^{1 / 2}$ transformed. 
In accordance with the present study, several authors reported that it is easier to achieve good quantities of spray deposition in the lower thirds of tree crops due to the higher exposure of this part of the plants to the equipment nozzles (SCUDELER et al., 2004; FERNANDES; FERREIRA; OLIVEIRA, 2010; RAMOS et al., 2007). It is important to note that the spray distribution on the plants should be as homogeneous

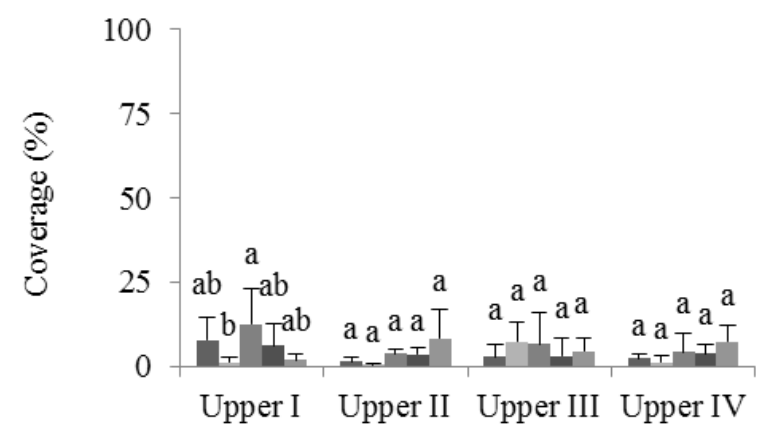

as possible, leading to satisfactory pest control efficiency.

In the upper thirds of the coffee plants, significant differences between treatments were only observed in the first quadrant, as the treatment with the PRV-13 sprayer and 15\% mineral oil in the spray liquid resulted in the highest percentage of leaf coverage (Figure 4). For the remaining quadrants, no differences were observed between spraying solutions or between sprayers.

Figure 4. Mean coverage (\%) of water-sensitive paper for each quadrant of the upper parts of coffee plants. VC $=7.57 \%$. Means followed by the same letter for each quadrant were not significantly different according to Tukey's test $(\mathrm{p} \leq 0.05)$. $* \mathrm{MO}$ : mineral oil Argenfrut ${ }^{\circledR}$. ${ }^{\dagger}$ Data $\operatorname{arc} . \operatorname{sen}(\mathrm{x} / 100)^{1 / 2}$ transformed.

In the lower thirds of the plants, higher mean coverage values were observed for quadrants I and III, similarly to the spray deposition results (Figure 5). In the third quadrant, only the treatment with the Arbus 2000 sprayer and $0.5 \%$ mineral oil was higher than the remaining treatments. This result was most likely due to the equipment characteristics, such as droplet size generated by hydraulic spray nozzles, number of nozzles, and distance of the nozzles to the plant crown, beyond the largest volume applied (400 1/ha).

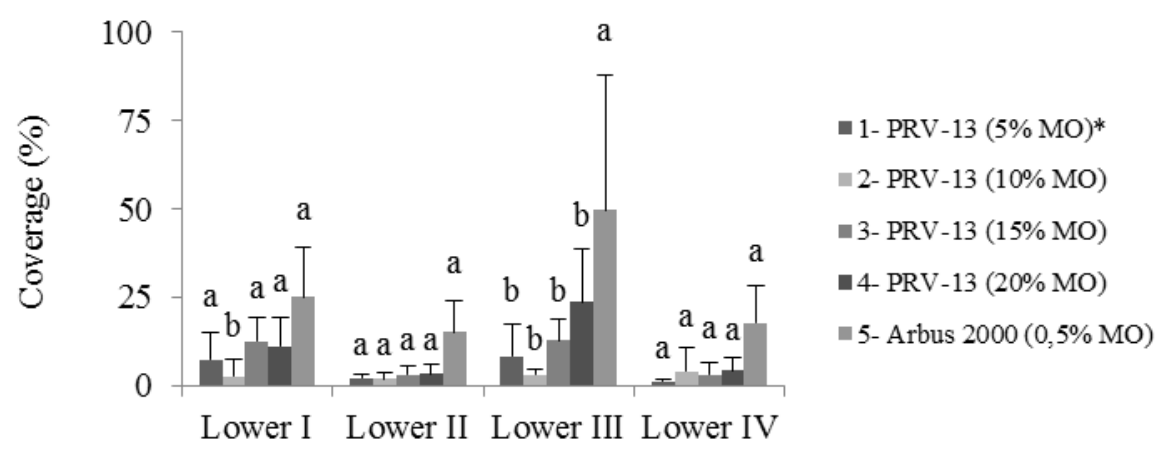

Figure 5. Mean coverage (\%) of water-sensitive paper for each quadrant of the upper parts of coffee plants. CV $=24.67 \%$. Means followed by the same letter for each quadrant were not significantly different according to Tukey's test $(\mathrm{p} \leq 0.05)$. *MO: mineral oil Argenfrut ${ }^{\circledR}$. ${ }^{\dagger}$ Data $\operatorname{arc} . \operatorname{sen}(\mathrm{x} / 100)^{1 / 2}$ transformed.

Miranda et al. (2012) also compared pneumatic and hydraulic sprayers at different volumes on coffee plants and observed that applications with the hydraulic sprayer resulted in higher deposits on the lower parts of the plants. In addition, the application with the pneumatic sprayer was more homogeneous, contributing to a higher quality of application.

In sprayers for tree crops, designs maintaining a minimum effective distance between each nozzle and the respective target improve the uniformity of the deposition and decrease the drift. In addition, the use of ducts (towers and vertical or 
horizontal lances) is becoming increasingly popular amongst manufacturers, especially in regard to searching for better deposition rates on the buffer zone, improving the quality of spraying and decreasing residues (DEVEAU, 2009).

Therefore, when dealing with the types of equipment valued, it is noticed that the sprayer PRV-13 showed better conditions of use when compared to the 2012 version, both the increase in water volume (70 1/ha to $100 \mathrm{l} / \mathrm{ha}$ ), the modification incorporated by the manufacturer, especially the type of air nozzle (effervescent) capable of producing droplets with larger size and good uniformity.

\section{CONCLUSION}

The reduced volume application, provided by the prototype sprayer of a pneumatic nozzles with the effervescent type compared to traditional airblast, presents proper conditions of use, especially in relation to deposit and coverage of spray liquid over coffee leaves.

\section{ACKOWLEDGMENTS}

The authors wish to thank the São Paulo Research Foundation (Fundação de Amparo à Pesquisa do Estado de São PauloFAPESP), process 2011/11928-9 and 2011/20088-4.

RESUMO: O objetivo do trabalho foi avaliar a eficiência da aplicação em volume reduzido a partir do protótipo de um pulverizador com bocais pneumáticos voltado ao controle do bicho-mineiro do cafeeiro (Leucoptera coffeella). Avaliaram-se diferentes tipos de bocais pneumáticos (jato plano, jato cônico, modelo AT-1000 e efervescente), na aplicação de caldas inseticidas com concentrações de 5, 10, 15 e 20\% (v/v) de óleo mineral aplicadas em volume reduzido e $0,5 \%$ aplicado via pulverizador convencional de jato transportado. Os parâmetros da tecnologia de aplicação estudados em condições de laboratório e campo foram: tamanho de gotas $(\mu \mathrm{m})$; depósito de marcador $\left(\mu \mathrm{g} / \mathrm{cm}^{2}\right)$ e cobertura foliar (\%). A aplicação em volume reduzido, proporcionada pelo protótipo de um pulverizador com bocais pneumáticos do tipo efervescente comparada ao turbo-pulverizador tradicional, apresenta adequadas condições de uso, principalmente em relação ao depósito e cobertura de calda sobre folhas de cafeeiro.

PALAVRAS-CHAVE: Coffea arabica. Tecnologia de aplicação. Redução de volume. Gotas.

\section{REFERENCES}

BALAN, M. G.; ABI SAAB, O. J. G.; SASAKI, E. H. Distribuição da calda na cultura da videira por turboatomizador com diferentes configurações de pontas. Ciência Rural, Santa Maria, v. 36, n. 3, p. 731-738, mai-jun, 2006. http://dx.doi.org/10.1590/S0103-84782006000300003

CAMARGO, A. P.; CAMARGO, M. B. P. Definição e esquematização das fases fenológicas do cafeeiro arábica nas condições tropicais do Brasil. Bragantia, Campinas, v. 60, n. 1, p. 65-68, 2001.

http://dx.doi.org/10.1590/S0006-87052001000100008

CUNHA, J. P. A. R.; BUENO, M. R.; FERREIRA, M. C. Diâmetro de gotas de pontas de pulverização com adjuvantes de uso agrícola. Planta Daninha, Viçosa, v. 28, n. spe, p. 1153-1158, 2010.

DEVEAU, J. Six elements of effective spraying in orchards and vineyards. Ontário: Ministry of Agriculture, Food and Rural Affairs, 2009. (Factsheeh Order, 09-39).

FERNANDES, A. P.; FERREIRA, M. C.; OLIVEIRA, C. A. L. Eficiência de diferentes ramais de pulverização e volumes de calda no controle de Brevipalpus phoenicis na cultura do café. Revista Brasileira de Entomologia, v. 54, n. 1, p. 130-135, março 2010. http://dx.doi.org/10.1590/S0085-56262010000100018

FERNANDES, A. P.; PARREIRA, R. S.; FERREIRA, M. C.; ROMANI, G. N. Caracterização do perfil de deposição e do diâmetro de gotas e otimização do espaçamento entre bicos na barra de pulverização.

Engenharia Agrícola, Jaboticabal, v. 27, n. 3, p. 728-33, 2007. 
FERNANDES FILHO, E. I; VALE, F. X. R.; ZAMBOLIM, L.; LIBERATO, J. R. 2002. Software QUANT v.1.0.0.22 - Quantificação de Doenças de Plantas. Universidade Federal de Viçosa, CD-ROM.

FERREIRA, M. C.; LEITE, G. J.; LASMAR, O. Cobertura e depósito de calda fitossanitária em plantas de café pulverizadas com equipamento original e adaptado para plantas altas. Bioscience Journal, Uberlândia, v. 29, Supplement 1, p. 1539-1548, Nov. 2013.

LEFEBVRE, A. H.; WANG, X. F.; MARTYIN, C. A. Spray Characteristics of Aerated-Liquid Pressure Atomizers, J. Propulsion, v. 4, n. ${ }^{\circ}$ 4, 1988.

MATTHEWS, G. A. Pesticide application methods. 2nd ed. Oxford: Blackwell, 2000. 405p. http://dx.doi.org/10.1002/9780470760130

MEWES, W. L. C.; TEIXEIRA, M. M.; FERNANDES, H. C.; ZANUNCIO, J. C.; TIBURCIO, R. A. S. Parâmetros característicos da pulverização pneumática em copas de árvores de eucalipto. Revista Árvore, Viçosa-MG, v. 39, n. 4, p. 635-640, 2015.

MINGUELA, J. V.; CUNHA, J. P. A. R. Manual de aplicação de produtos fitossanitários. Viçosa, MG: Aprenda Fácil, 2010. 588p.

MIRANDA, G. R. B.; RAETANO, C. G.; SILVA, V. C.; CUNHA, M. D. Q.; CARVALHO, R. H.; PINHEIRO, J. M.; GONÇALVES, M. P.; REINATO, C. H. R.; PAIVA, L. C.; ARAÚJO, D. Avaliação dos depósitos da pulverização em frutos de cafeeiro utilizando dois equipamentos associados a diferentes volumes de calda. Revista Agrogeoambiental, Pouso Alegre, v. 4, n. 1, p. 15-20, abr. 2012.

OCHOWIAK, M.; BRONIARZ-PRESS, L. Atomization performance of effervescent atomizers with gas-liquid internal mixing. Polish Journal of Chemical Technology, v. 10, n. 3, p. 38-41, 2008.

http://dx.doi.org/10.2478/v10026-008-0034-2

OLIVEIRA, M. L.; MACHADO-NETO, J. G. Use of tracer in the determination of respiratory exposure and relative importance of exposure routes in safety of pesticide applicators in citrus orchards. Bulletin of Environmental Contamination and Toxicology, Florida, v. 70, n. 3, p. 415-21, 2003. http://dx.doi.org/10.1007/s00128-003-0002-8

RAMOS, H. H.; YANAI, K.; CORRÊA, I. M.; BASSANEZI, R. B.; GARCIA, L. C. Características da pulverização em citros em função do volume de calda aplicado com turbopulverizador. Engenharia Agrícola, Jaboticabal, v. 27, n. especial, p. 56-65, 2007.

SCUDELER, F.; RAETANO, C. G.; ARAÚJO, D.; BAUER, F. C. Cobertura da pulverização e maturação de frutos do cafeeiro com ethephon em diferentes condições operacionais. Bragantia, Campinas, v. 63, n. 1, p. 129-139, 2004. http://dx.doi.org/10.1590/S0006-87052004000100013

SHARMA, H. C. Biotechnological approaches for pest management and ecological sustainability. Florida, CRC Press, 2008, 546p. http://dx.doi.org/10.1201/9781420088489

WORLD HEALTH ORGANIZATION (WHO). Public Health Impacts of Pesticides Used in Agriculture (WHO in collaboration with the United Nations Environment Programme, Geneva, 1990). 